\title{
MENINGKATAN KEMAMPUAN KOMUNIKASI MATEMATIS SISWA MELALUI MODEL PEMBELAJARAN PREDICT OBSERVE EXPLANATION
}

\author{
Tina Sri Sumartini \\ STKIP GARUT; tina.srisumartini@gmail.com
}

\begin{abstract}
Based on previous observations note that the ability of some students' mathematical communication is still lacking. Therefore, it is necessary to improve students' mathematical communication ability by using Predict Observe Explanation (POE) learning model. The purpose of this study is to describe the process of implementing mathematics learning through the Predict Observe Explanation (POE) learning model in an effort to improve students' communication skills. The type of this research is Classroom Action Research (PTK) which consists of two cycles and each cycle is done with 4 stages of planning, action implementation, observation, and reflection. The subjects of this study are students of class XI SMK Al Hikmah Garut. The results showed POE learning model can improve students' mathematical communication ability with the learning stages: 1) predict: predicting the temporary answer of the given mathematical problem; 2) observe: observing other similar issues through teacher demonstrations; 3) explanation: presenting predictions and observations.

Keywords: Mathematical Communication Skill, Predict Observe Explanation Learning Model
\end{abstract}

\begin{abstract}
Abstrak
Berdasarkan pengamatan sebelumnya diketahui bahwa kemampuan komunikasi matematis sebagian siswa masih kurang. Oleh karena itu, perlu dilakukan upaya peningkatan kemampuan komunikasi matematis siswa dengan salah satunya menggunakan model pembelajaran Predict Observe Explanation (POE). Tujuan penelitian ini adalah mendeskripsikan proses pelaksanaan pembelajaran matematika melalui model pembelajaran Predict Observe Explanation (POE) dalam upaya meningkatkan kemampuan komunikasi siswa. Jenis penelitian ini adalah Penelitian Tindakan Kelas (PTK) yang terdiri dua siklus dan setiap siklus dilakukan dengan 4 tahapan yaitu perencanaan, pelaksanaan tindakan, observasi, dan refleksi. Subjek penelitian ini adalah siswa kelas XI SMK Al Hikmah garut. Hasil penelitian menunjukkan bahwa model pembelajaran POE dapat meningkatkan kemampuan komunikasi matematis siswa dengan tahapan pembelajaran : 1) predict yaitu memprediksi jawaban sementara dari permasalahan matematika yang diberikan; 2) observe yaitu mengamati persoalan lain yang serupa melalui demonstrasi guru; 3) explanation yaitu mempresentasikan hasil prediksi dan pengamatan.
\end{abstract}

Kata Kunci: Kemampuan Komunikasi Matematis, Model Pembelajaran Predict Observe Explanation 


\section{PENDAHULUAN}

Pendidikan

matematika

menjadi bagian yang penting dalam upaya melestarikan pengetahuan dan mengembangkan kemampuan berpikir siswa. Dalam National Council of Teacher of Mathematics (NCTM, 2000) pelaksanaan pembelajaran matematika, harus memperhatikan lima kemampuan matematis yaitu: koneksi (connections), penalaran (reasoning), komunikasi (communications), pemecahan masalah (problem solving), dan representasi (representations). Oleh karena itu, salah satu kemampuan yang harus ditingkatkan adalah kemampuan komunikasi matematis. Berdasarkan hasil pengamatan pra penelitian, terlihat beberapa siswa di SMK AL Hikmah Garut masih kurang memiliki kemampuan komunikasi matematis. Hal ini terlihat dari salah satunya masih banyaknya kesalahan dalam menggambar grafik fungsi linear dan menyusun argumen tertulis secara matematis. Selain itu, dalam hal berdiskusi masih terlihat sebagian siswa kurang dapat berkomunikasi secara lisan dengan benar.

Dari penelitian yang dilakukan oleh Umar (2012) tentang "Membangun Komunikasi dalam Pembelajaran Matematika", disimpulkan bahwa komunikasi merupakan jantung dalam pembelajaran matematika. Hal ini berarti bahwa siswa harus mampu berkomunikasi baik secara lisan maupun tulisan sehingga pembelajaran matematika dapat dilakukan dalam bentuk interaksi antara guru dan siswa. Hal ini diperkuat oleh Baroody (1993) bahwa pembelajaran harus dapat membantu siswa dalam mengkomunikaiskan ide matematika melalui lima aspek komunikasi yaitu representing, listening, reading, discussing, dan writing.

Berdasarkan penjelasan tersebut, perlu dilakukan upaya peningkatan kemampuan komunikasi matematis dengan menggunakan metode yang relevan. Peneliti menduga bahwa model pembelajaran Predict Observe Explanation (POE) dapat digunakan dalam upaya meningkatkan kemampuan komunikasi matematis siswa. Model POE terdiri dari tiga tahap yaitu predict yaitu kegiatan pembelajaran yang diarahkan agar siswa bisa mengkonstruksi pengetahuannya dengan memprediksi jawaban dari permasalahan matematis yang diberikan oleh guru. Hal ini diduga dapat meningkatkan indikator kemampuan matematis yaitu merefleksikan dan menjelaskan pemikirannya mengenai ide dan hubungan matematika. Tahap observe yaitu kegiatan pembelajaran yang diarahkan agar siswa dapat mengamati permasalahan lain yang serupa sebagai upaya untuk mengevaluasi hasil prediksinya. Hal ini diduga dapat meningkatkan kemampuan matematis dalam hal memformulasikan definisi matematika dan generalisasi melalui 
metode penemuan, membaca wacana matematika dengan pemahaman, dan mengklarifikasi dan memperluas pertanyaan terhadap matematika yang dipelajarinya. Tahap explanation yaitu kegiatan pembelajaran yang diarahkan agar siswa mampu berkomunikasi dalam menyatakan ide matematika secara lisan maupun tulisan.

Tujuan dalam penelitian ini adalah untuk mengetahui bagaimana deskripsi model pembelajaran Predict Observe Explanation (POE) dapat meningkatkan

kemampuan komunikasi siswa. Untuk menjawab pertanyaan penelitian ini perlu dilakukan Penelitian Tindakan Kelas (PTK) yang menggunakan beberapa siklus dengan tahapan perencanaan, pelaksanaan tindakan, observasi, dan refleksi.

\section{LANDASAN/KAJIAN TEORI}

\section{A. Kemampuan Matematis Pendidikan \\ Komunikasi matematika} dimulai dari komunikasi antara guru dengan siswa. Guru harus mempunyai kemampuan dalam berkomunikasi baik secara lisan maupun tulisan. Komunikasi secara lisan, berkaitan dengan kemampuan guru dalam menyampaikan materi matematika sehingga dapat dipahami oleh siswa dan komunikasi secara tulisan berkaitan dengan kemampuan guru dalam menyampaikan konsep matematika dalam bentuk tulisan sehingga siswa bisa belajar selain ketika bersama guru. Bentuk komunikasi tulisan bisa berupa pembuatan buku ajar sebagai sarana transformasi ilmu pengetahuan. Selain guru, siswa pun harus memiliki kemampuan komunikasi dalam memahami konsep matematika dan dalam menyampaikannya kembali kepada orang lain.

Komunikasi menjadi kunci keberhasilan proses pembelajaran dimana guru dan siswa menyatu dalam lingkungan belajar yang ideal. Baroody (1993) mengemukakan lima aspek komunikasi, yaitu: representasi, mendengar, membaca, diskusi, dan menulis. Noraini mengemukakan bahwa menulis mendorong tingkat efektifitas kognitif yang memaksimalkan potensi belajar untuk memodifikasi dan merestrukturisasi pengetahuan matematika. Selanjutnya dikemukakan pula bahwa menulis dalam pembelajaran matematika memiliki kegunaan yaitu:

1. Menulis membantu siswa menjadi sadar apa yang mereka ketahui dan yang tidak diketahui, bisa dan tidak bisa dilakukan

2. Ketika siswa menulis, mereka terhubung dengan pengetahuan yang dimiliki sebelumnya.

3. Menulis membantu siswa merangkum pengetahuan mereka dan memungkinkan guru untuk memahami alur pemikiran siswa

4. Menulis membantu siswa memunculkan ide-ide yang baru

5. Menulis membantu siswa merefleksikan apa yang mereka ketahui

6. Menulis membantu siswa membangun matematika untuk mereka sendiri.

Matematika syarat akan simbol-simbol sehingga dalam 
memahaminya memerlukan kemampuan komunikasi. Menurut Sumarmo (2000), pengembangan bahasa dan simbol dalam matematika bertujuan untuk mengkomunikasikan matematika sehingga siswa mampu untuk:

1. Merefleksikan dan menjelaskan pemikirannya mengenai ide dan hubungan matematika

2. Memformulasikan definisi matematika dan generalisasi melalui metode penemuan

3. Menyatakan ide matematika secara lisan dan tulisan

4. Membaca wacana matematika dengan pemahaman

5. Mengklarifikasi dan memperluas pertanyaan terhadap matematika yang dipelajarinya

6. Menghargai keindahan dan kekuatan notasi matematika dan peranannya dalam mengembangkan ide matematika.

Elliot dan Kenney (1996) menyatakan bahwa kemampuan komunikasi terdiri dari empat aspek berikut:

1. Kemampuan tata bahasa yaitu kemampuan siswa untuk memahami kosakata dan struktur yang digunakan dalam matematika seperti: merumuskan suatu definisi dari istilah matematika, menggunakan simbol/notasi dan operasi matematika secara tepat.

2. Kemampuan memahami wacana yaitu kemampuan siswa untuk memahami serta mendeskripsikan informasi penting dari permasalahan matematika.

3. Kemampuan sosiolinguistik yaitu kemampuan siswa dalam menginterpretasikan gambar, grafik atau kalimat matematika ke dalam uraian yang sesuai dan menyajikan permasalahan matematis ke dalam bentuk gambar atau grafik.

4. Kemampuan strategis yaitu kemampuan membuat prediksi atas hubungan antar konsep dalam matematika, menyampaikan ide matematika dengan gambar atau grafik, dan menyelesaikan persoalan secara runtut.

Adapun indikator kemampuan komunikasi matematis yang digunakan dalam penelitian ini adalah merefleksikan dan menjelaskan pemikirannya mengenai ide dan hubungan matematika, kemampuan membuat prediksi atas hubungan antar konsep dalam matematika, menyatakan ide matematika secara lisan dan tulisan, membaca wacana matematika dengan pemahaman, dan mengklarifikasi dan memperluas pertanyaan terhadap matematika yang dipelajarinya.

\section{B. Pembelajaran Predict Observe Explanation (POE)}

Model pembelajaran POE terdiri dari tiga kegiatan yaitu 'Tahap predict adalah tahap dimana siswa membuat prediksi mengenai sesuatu yang sedang dihadapinya. Prediksi bermula dari pengetahuan awal yang dimilikinya dan didukung oleh sumber-sumber lain yang sesuai dengan kebutuhan.Tahap observe yaitu tahap dimana siswa mengamati dan menuliskan sesutu yang menjadi objek pengamatan berdasarkan prediksi yang dimilikinya. Tahap explanation yaitu tahap kegiatan siswa untuk menjelaskan hasil pengamatannya dan membahas hubungan yang terjadi antara prdiksi 
dengan pengamatan yang telah dilakukan. Dalam tahap predict dan observe mungkin saja terdapat ketidaksesuaian sehingga harus diluruskan pada tahap explanation.

Model pembelajaran POE memberikan kesempatan kepada siswa menghubungkan pengetahuan awal yang dimilikinya dengan pengetahuan baru dalam lingkungan sekitar. Siswa akan mampu memahami masalah dengan lebih mendalam dan menghubungkan berbagai aspek yang dalam masalah tersebut. Ketika membuat prediksi, siswa melibatkan pemahaman yang telah dimilikinya untuk untuk mengkonstruksi pemahaman baru melalui kepekaannya terhadap masalah yang sedang dihadapinya. Tahap prediksi juga memberikan kesempatan bagi siswa untk secara eksplisit mengakui pengetahuan awal mereka sebagai titik awal untuk perubahan konseptual (Costu, Ayas, \& Niaz, 2010; Johnston\&Scott, 1991). Dalam hal ini memberi keuntungan bagi guru untuk mengetahui kemampuan awal siswa sehingga dapat menentukan langkah yang tepat agar proses pembelajaran dapat berlangsung dengan tepat sasaran.
Tahap kedua dari pembelajaran POE adalah observasi dimana siswa dapat memahami konsep secara lebih mendalam. Kemungkinan siswa akan mengalami konflik kognitif karena menghadapi situasi dimana prediksi berbeda dengan keadaan yang sebenarnya. Selanjutnya siswa harus mampu merubah konsep yang sudah didesain dalam pikirannya menjadi konsep yang baru berdasarkan pengamatannya. Hal ini tentunya tidak terlepas dari peran guru dalam mengajukan beberapa pertanyaan yang akan menuntun siswa untuk menggabungkan pengetahuan yang sudah dimilikinya dengan pengetahuan yang baru diperoleh (Costu, et al, 2010).

Tahap ketiga yaitu siswa memberi penjelasan dari hasil prediksi dan observasi yang telah dilakukannya. Pada tahap ini siswa dapat lebih memahami konsep yang sedang dipelajari karena berawal dari prediksi yang telah dibuatnya kemudian diperkuat dengan pengetahuan baru yang diperoleh lewat observasi. Pada tahap ini juga siswa bisa saling bertukah pikiran dan membenarkan kesalahan konsep yang telah dilakukan pada tahap sebelumnya. Tahapan POE dapat dilihat pada tabel berikut

Tabel 1

Tahapan Model Pembelajaran POE

\begin{tabular}{|c|c|c|}
\hline Tahapan & Kegiatan Dosen & Kegiatan Mahasiswa \\
\hline \multicolumn{3}{|c|}{ Predict } \\
\hline Pendahuluan & Guru menyeting pembelajaran & $\begin{array}{l}\text { siswa mengkondisikan diri } \\
\text { mengikuti aturan yang dibuat }\end{array}$ \\
\hline Eksplorasi & $\begin{array}{l}\text { Guru memberikan pertanyaan } \\
\text { untuk pengidentifikasian dan }\end{array}$ & $\begin{array}{l}\text { siswa menjawab pertanyaan } \\
\text { guru dengan membangkitkan }\end{array}$ \\
\hline
\end{tabular}




\begin{tabular}{|c|c|c|}
\hline Tahapan & Kegiatan Dosen & Kegiatan Mahasiswa \\
\hline & $\begin{array}{l}\text { pengaktifan pengetahuan awal } \\
\text { pembelajar }\end{array}$ & $\begin{array}{l}\text { pengetahuan awal yang telah } \\
\text { dimilikinya }\end{array}$ \\
\hline Prediksi & $\begin{array}{lrr}\text { Guru } & \text { memberikan } & \text { uraian } \\
\text { masalah } & \text { sehingga } & \text { siswa } \\
\text { mampu } & \text { membuat } & \text { prediksi } \\
\text { tahap penyelesaian } & \end{array}$ & $\begin{array}{l}\text { siswa membuat prediksi } \\
\text { penyelesaian masalah } \\
\text { matematis berdasarkan tahap } \\
\text { eksplorasi }\end{array}$ \\
\hline \multicolumn{3}{|c|}{ Observe } \\
\hline Mengamati & $\begin{array}{lcc}\text { Guru } & \text { mengarahkan } & \text { siswa } \\
\text { untuk } & \text { mengamati } & \text { konsep } \\
\text { masalah yang sesungguhnya }\end{array}$ & $\begin{array}{l}\text { siswa mengamati demonstrasi } \\
\text { guru secara mendetail }\end{array}$ \\
\hline Restrukturisasi & $\begin{array}{l}\text { Guru merestrukturisasi } \\
\text { pengetahuan awal pembelajar } \\
\text { agar terbentuk konsep yang } \\
\text { diharapkan }\end{array}$ & $\begin{array}{l}\text { siswa mulai menggabungkan } \\
\text { pengetahuan awal yang } \\
\text { dimilikinya } \\
\text { pengetahuan baru yang sudah } \\
\text { ditemukan }\end{array}$ \\
\hline Aplikasi & $\begin{array}{l}\text { Guru meminta siswa untuk } \\
\text { menerapkan konsep yang baru } \\
\text { terhadap permasalahan yang } \\
\text { lain }\end{array}$ & $\begin{array}{l}\text { siswa mengaplikaiskan konsep } \\
\text { yang telah diperolehnya untuk } \\
\text { menyelesaikan permasalahan } \\
\text { yang baru }\end{array}$ \\
\hline \multicolumn{3}{|c|}{ Explanation } \\
\hline Diskusi & $\begin{array}{l}\text { Guru meminta siswa untuk } \\
\text { menjelaskan hasil temuannya } \\
\text { dan mendiskusikannya }\end{array}$ & $\begin{array}{l}\text { siswa saling menjelaskan hasil } \\
\text { temuannya } \\
\text { mendiskusikannya }\end{array}$ \\
\hline $\begin{array}{ll}\text { Review dan } \\
\text { Evaluasi }\end{array}$ & $\begin{array}{l}\text { Guru meninjau kembali apa } \\
\text { yang telah terjadi pada diri } \\
\text { pembelajar berkaitan dengan } \\
\text { suatu konsep/pembelajaran }\end{array}$ & $\begin{array}{llr}\text { Siswa } & \text { meninjau } & \text { kembali } \\
\text { konsep } & \text { berdasarkan } & \text { hasil } \\
\text { diskusi } & & \end{array}$ \\
\hline
\end{tabular}

\section{METODE PENELITIAN}

Jenis penelitian ini adalah Penelitian Tindakan Kelas (PTK) yang dilaksanakan pada semester 3 tahun pelajaran 2015/2016. Subjek penelitian adalah siswa kelas XI TI 2 SMK AL Hikmah Garut. Kegiatan pembelajaran matematika dirancang dengan PTK dalam upaya meningkatkan kemampuan komunikasi siswa kelas XI TI 2 SMK
AL Hikmah Garut dengan menggunakan pembelajaran Predict Observe Explanation (POE). PTK ini dibangun oleh dua siklus sesuai dengan kecukupan pelaksanaan penelitian. Lewins dan Mc Niff menggambarkan PTK sebagai tahapan spiral yang terdiri dari empat tahapan yaitu perencanaan, tindakan, observasi, dan refleksi. Keempat tahap tersebut digambarkan sebagai berikut 


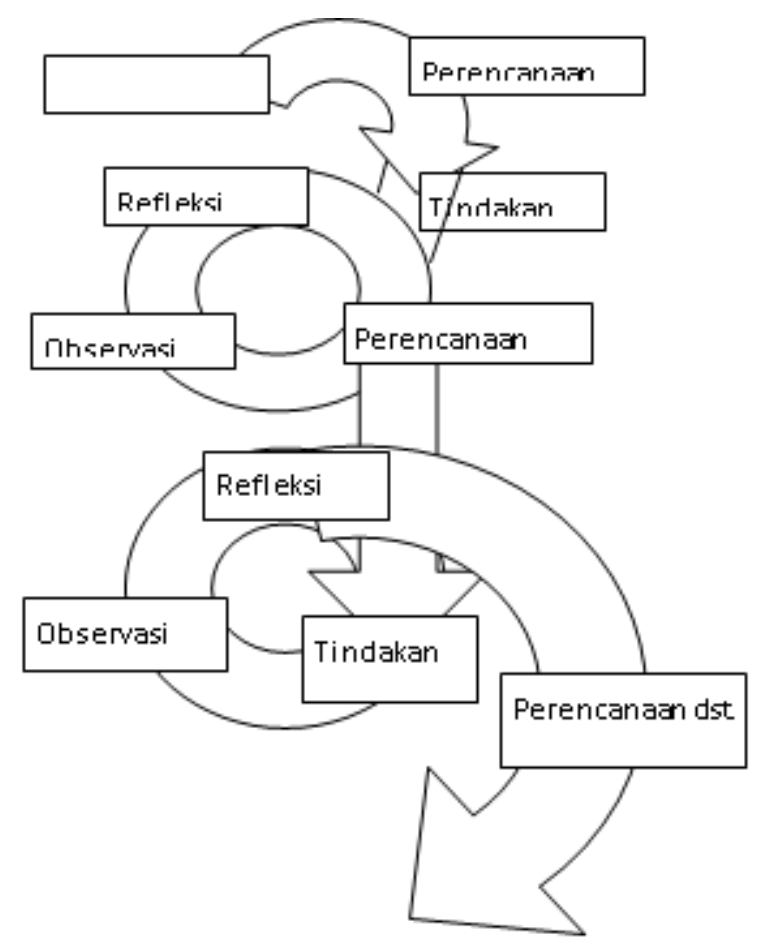

Gambar 1

Tahapan Penelitian Tindakan kelas

HASIL PENELITIAN DAN PEMBAHASAN

\section{A. HASIL PENELITIAN}

PTK ini terdiri dari 2 siklus dengan tahapan sebagai berikut:

\section{Siklus 1}

1. Perencanaan

Peneliti mulai melakukan

kegiatan perencanaan dengan menyiapkan perangkat pembelajaran (Rencana

Pelaksanaan Pembelajaran (RPP), Lembar Kerja Siswa (LKS), dan lembar penilaian), Instrumen soal kemampuan komunikasi matematis.

2. Pelaksanaan

Tahap pelaksanaan dilakukan berdasarkan tahap perencanaan dengan menerapkan pembelajaran POE. Sebelum pembelajaran siswa sudah dikondisikan secara berkelompok sesuai dengan daftar yang telah dibuat oleh peneliti.

\section{Tahap 1: Predict}

Pembelajaran dimulai dengan mengajukan berbagai pertanyaan prasyarat untuk mengaktifkan pengetahuan awal siswa. Kemudian peneliti membagikan LKS kepada setiap kelompok siswa dan meminta siswa untuk mendiskusikan permasalahan dalam LKS dan membuat prediksi mengenai jawaban sementara dari permasalahan tersebut.

\section{Tahap 2: Observe}

Tahap observe yaitu mengamati demonstrasi guru. Guru mengajukan berbagai pertanyaan yang berkaitan dengan pengamatan mereka Setelah mengamati, setiap kelompok 
berdiskusi kembali untuk
memperbaiki kekurangan dari
jawaban mereka.

\section{Tahap 3: Explanation}

Setelah siswa melakukan pengamatan dan berdiskusi, maka pada tahap explanation perwakilan kelompok siswa mempresentasikan hasil diskusi kelompoknya sehingga terjadi diskusi antar kelompok siswa dan juga peneliti.

3. Pengamatan

Peneliti mengamati setiap
4. Refleksi

Hasil refleksi dgunakan untuk menyimpulkan data dan sebagai informasi pertimbangan perencanaan pada siklus kedua.

\section{Siklus 2}

Tahapan pelaksanaan siklus kedua sama dengan tahapan pelaksanaan pada siklus kesatu.

\section{Perbandingan kemampuan} komunikasi matematis siswa pada siklus 1 dan siklus 2 dapat dilihat dalam gambar berikut. proses pembelajaran.

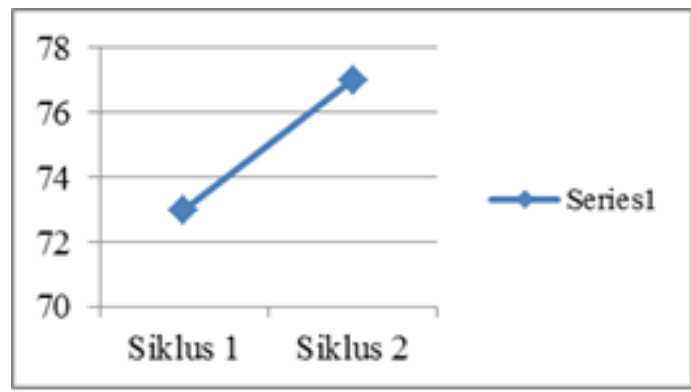

Gambar 2

Perbandingan Kemampuan Komunikasi Matematis pada Siklus 1 dan Siklus 2

\section{B. Pembahasan}

Penelitian ini merupakan penelitian tindakan kelas dalam upaya meningkatkan kemampuan komunikasi matematis siswa dengan menerapkan pembelajaran POE.

Berdasarkan hasil tes kemampuan komunikasi matematis siswa, pada siklus 1 masih ada 23,25\% siswa yang kemampuan komunikasi matematisnya masih rendah. Hal tersebut diakibatkan karena siswa masih merasa baru dalam melaksanakan pembelajaran dengan model POE terutama dalam memprediksi jawaban dari masalah yang diberikan. Menurut Elliot dan Kenney (1996) salah satu kemampuan komunikasi matematis adalah kemampuan membuat prediksi atas hubungan antar konsep dalam matematika. Oleh karena itu, dilakukan siklus kedua untuk mengoptimalkan pelaksanaan pembelajaran dengan model POE sehingga kemampuan komunikasi matematis siswa dapat meningkat. Hal yang dilakukan adalah dengan mempertajam pertanyaan pada tahap prediksi dari siklus ke dua sehingga siswa mampu memahami maksud dari masalah yang disajikan. Hal ini 
terjadi terjadi peningkatan kemampuan komunikasi matematis siswa dari siklus 1 ke siklus 2 . Hal ini sesuai dengan pendapat Costu, et al (2010) bahwa mengajukan beberapa pertanyaan yang akan menuntun siswa untuk menggabungkan pengetahuan yang sudah dimilikinya dengan pengetahuan yang baru diperoleh.

Setelah siklus kedua dilaksanakan, masih ada $7 \%$ siswa yang masih kurang kemampuan komunikasinya. Namun demikian, terjadi peningkatan kemampuan komunikasi matematis siswa dari siklus 1 ke siklus 2 sebesar $4 \%$.

Hasil di atas menunjukkan bahwa model pembelajaran POE berperan dalam upaya meningkatkan kemampuan komunikasi siswa. Hal ini dikarenakan pembelajaran POE memiliki tahapan penting dalam meningkatkan kemampuan komunikasi matematis siswa. Pada tahap predict, siswa mulai mengaktifkan pengetahuan sebelumnya dan membuat prediksi terhadap permasalahan. Pada tahap ini, siswa merefleksikan dan menjelaskan pemikirannya mengenai ide dan hubungan matematika. Selain itu, siswa dapat mengoptimalkan pengetahuan awal yang dimilikinya untuk membangun pengetahuan baru dengan proses prediksi. Tahap prediksi memberikan kesempatan bagi siswa untuk secara eksplisit mengakui pengetahuan awal mereka sebagai titik awal untuk perubahan konseptual
(Costu, Ayas, \& Niaz, 2010; Johnston\&Scott, 1991). Pada tahap observe, siswa melakukan pengamatan terhadap demonstrasi guru sehingga merestrukturisasi pengetahuan awal yang dimiliki dan mengaplikasikannya dalam pemecahan masalah fungsi kuadrat. Dalam tahap ini siswa dapat memformulasikan konsep dan mengklarifikasi hasil prediksinya berkaitan dengan jawaban dari permasalahan matematika. Pada tahap ketiga explanation, siswa mempresentasikan hasil prediksi dan pengamatannya sehingga terjadi diskusi antar siswa dan guru.

\section{KESIMPULAN DAN SARAN Kesimpulan}

Model pembelajaran POE dapat meningkatkan kemampuan komunikasi matematis siswa dengan tahapan pembelajaran : 1) predict yaitu memprediksi jawaban sementara dari permasalahan matematika yang diberikan; 2) observe yaitu mengamati persoalan lain yang serupa melalui demonstrasi guru; 3) explanation yaitu mempresentasikan hasil prediksi dan pengamatan.

\section{Saran}

1. Model pembelajaran POE perlu dikembangkan lebih lanjut dalam penelitian-penelitian berikutnya untuk meningkatkan aspek kemampuan lain.

2. Peneliti lain yang ingin melakukan penelitian dengan model pembelajaran POE agar lebih memperhatikan lagi alokasi waktu yang digunakan sehingga 
setiap tahap pembelajaran dapat dilaksanakan dengan optimal.

3. Peneliti yang lain bisa mencoba untuk menggunakan pembelajaran POE dalam upaya meningkatkan kemampuan komunikasi siswa pada jenjang sekolah yang berbeda dan materi yang berbeda

\section{DAFTAR PUSTAKA}

Baroody, A.J. (1993). Problem Solving, Reasioning, and Communicating, $K-8$ Helping Children Think mathematically. New York: Macmillan Publising Company.

Coştu, B., Ayas, A., \& Niaz, M. (2010). Promoting conceptual change in first year students' understanding of evaporation. Chemistry Education Research and Practice, 11(1), 5-16.

Elliot, P. C \& Kenney, M. J . (1996). Communication In Mathematics, K-12 \& Beyond. USA : NCTM.

Johnston, K., \& Scott, P. (1991). Diagnostic teaching in the science classroom: Teaching/learning strategies to promote development in understanding

about

conservation of mass on dissolving. Research in Science \& Technological Education, 9(2), 193-212.

National Council of Teacher of Mathematics (NCTM). (2000). Curriculum and Evaluation Standars for School Mathematics, United States of America: The National Council of Teachers of Mathematics Inc.

Noraini, I. (2009). Enhancing Students' Understanding in Calculus Trough Writing. International Electronic Jurnal of Mathematics Education, 4 (1), ISSN 1306-3030.

Sumarmo, U. (2000). Pengembangan Model Pembelajaran Matematika untuk Meningkatkan Kemampuan Intelektual Tingkat Tinggi Siswa Sekolah Dasar. Laporan Penelitian FMIPA UPI. Tidak diterbitkan

Umar, W. (2012). Membangun Kemampuan Komunikasi Matematis dalam Pembelajaran Matematika. Infinity, 1(1). 